\title{
The Quranic Theory of Education: Methodological Reflections
}

\author{
Omar Nakib \\ National High School for Teachers’ Education, Algiers, onakib@yahoo.com
}

\begin{abstract}
This study is an investigation into the components of the methodological approach that must be adopted to tackle the Quranic theory of education. The purpose is to suggest some methodological requirements to approach such a theory in a form of a methodological framework that may enable us to elaborate the components of a new Islamic theory of education. The study involved an investigation into the exegesis of Al-Qur'ān verses. Qualitative methodology was adopted, and content analysis was employed to examine the related data. Three questions have been addressed: Does Al-Qur'ān involve a theory of education? What are the required methodological considerations to address the Quranic model of education as prescribed in Al-Qur'ān? What are the methodological requirements necessary to formulate the Quranic Model of Education? The findings show that Al-Qur'ān has prescribed a set of educational teachings as a methodological framework that must be considered whenever there is an attempt to unveil the revealed Quranic theory of education. To conclude, it is recommended to observe such methodological requirements to adequately unveil the essential features of the Quranic model of education. This is to pave the way for Muslim educational practitioners to actualize the meanings of the desired model of man as prescribed by Al-Qur'ān in their educational practice.
\end{abstract}

Keywords: revelation, al-Qur'ān, quranic model, frame of reference, methodological requirements

\section{Introduction}

It is well known among Muslims that Islam is the last message of Allah (swt) to mankind. So, it would be axiomatic that since it is directed to mankind ${ }^{1}$ in order to orient them in the organizing of their life according the Divine Will in a purposeful manner ${ }^{2}$, such a message should be as comprehensive as to encompass all fields of human life. That is why, Islam is not merely concerned with strengthening human being's individual spiritual relation with the Lord, Allah (swt), even though this is a primordial tenet in the

\footnotetext{
${ }^{1}$ See: Verse 28 from surah Sabā'

${ }^{2}$ See: Verse 89 from surah an-Nahl.
} 
Islamic creed. Rather, it is concerned with observing beliefs, values, ethics and different types of legislation that ensure the role of orientation, control and guidance of human thought and action ${ }^{3}$ to make human life significant and distinguished from other's Allah (swt) creatures. For this reason, it becomes imperative to see Al-Qur'ān's model of education, not only as an educational model that encompasses the meanings of the Divine Will that must be instilled in human spirit, but also as a methodological approach that assumes the role of guiding human mind in the discovery of the Quranic theory of education.

By virtue of its being a revealed way of life that ensures human strength, righteousness, piety and purity that altogether contribute to the formation of a perfect model of man in the present life and ensure for him the eternal happiness in the hereafter. To elucidate the issue of the comprehensiveness of the Quranic worldview, Al-Qur'ān says in sürah al-An'ām:

Say: Lo1 my worship and my sacrifice and y living and my dying are for Allah, Lord of the Worlds (6: 162)

and

...We have neglected nothing in the Book (of Our decrees)

Then unto their Lord they will be gathered (6: 38)

and in surah an-Nahl

... and We reveal the Scripture unto thee as an exposition of all things, and a guidance and a mercy and good tidings for those who are surrendered to Allah (16: 89).

That is why, since the beginning of its revelation (al-wahy), as the last message of Allah (swt) to mankind, and the seal of all religions, Al-Qur'ān made it clear that its central concern is man. Meanwhile, the actualization of the meanings of honor and conferment of human race over all of other creatures is one of its utmost aims in human life. The actualization of those meanings pass through a purposeful process of qualifying the individual to successfully achieve the historical mission, as prescribed by the

3 To get more details about this issue see for instance: Seyyed Qutb, The Milestones (Beirut \& Damascus: I.I.F.S.O, The Holy Qur'ān Publishing House, 1978 and Fì Dhilāl Al-Qur'an (In the Shadow of the Qur'ān), $22^{\text {nd }}$ edition (Beirut: Dār ash- Shurūq, 1982. See also: Abū Hasan al-Nadwī, Mādhā Khașra al-Ālam Binhițāt al-Musliminn (What Did the World Loose with the Decline of the Muslims) (Damascus: Dār al-Kalām), 1999. 
Divine Will in order to reach the pleasure of his Lord, Allah (swt), the Creator, in the Day of Judgment and ensure a peaceful and eternal life.

This dual aim cannot be actualized but through a systematic process of educating human personality by the means of the transformation of his vital energy into social trends useful for the societal life. That is, to transform him from a natural being that lives for the sake of his natural needs, rather instinctual desires, into a socialized person ${ }^{4}$, a civilized being aware of:

$\circ$ the purpose of his existence,

$\circ$ the nature of his universal position,

$\circ$ the requirements of his noble mission in this life,

$\circ$ his destiny in the hereafter.

When looking into our Islamic historical heritage, we can find that such a process had been undertaken under the direct supervision and guidance of revelation (Al-Wahy) through the leadership of the Prophet Mohammad (s.a.w). The reading of the Prophet's sirah (biography) support such a view and may enlighten us on the matter.

To elucidate the Quranic treatment of the above issues, we shall attempt to answer three questions:

- Does Al-Qur'ān involve a theory of education?

- What are the required methodological considerations to address the Quranic model of education as prescribed in $\mathrm{Al}$ Qur'ān.

- What are the methodological requirements necessary to formulate the Quranic Model of Education?

\section{Does Al-Qur'ān Involve a Theory of Education?}

For the purpose of this study, we find it worthwhile to ask the following questions:

○ Does $A l$-Qur'ān involve any theory of education per se? In other words,

○ Does Al-Qur'ān treat the philosophical foundations upon which the theory of education stands?

\footnotetext{
${ }^{4}$ Malik Bennabi, Mīlād Mujtama ' (Damascus: Dār al-Fikr, 1986), 31, and On the Origins of Human Society, trans. Mohammad Țāhir al-Messawi (Kuala Lumpur: The Open Press, 1998), 33.
} 
- Are we in need to prove that Al-Qur'ān involves a certain theory or at least some assumptions about the philosophical foundations that form the basis upon which the theory of education stands?

Below is a summarized analysis of these queries.

It is axiomatic for Muslim people, at least, that Al-Qur'ān is the last Word of Allah (swt) to mankind. This is mentioned in many parts of Al-Qur'ān itself. For instance, Allah (swt) says in surah as-Shūrā,

And thus We, by Our command, sent inspiration (Angel Gabriel) to thee: Thou knewest not before what was revelation (Al-Wahy), and what was faith; but We have made the Qur'ān a Light, wherewith We guide such of Our servants as We will; and verily thou dost guide (men) to the straight Way, the Way of Allah, to Whom belongs whatever is in the heaven and whatever is in earth. Behold (how) all affairs tend towards Allah (Q. 42: 52).

and in surah an-Nahl

... and We have sent down to thee the book explaining all things, a Guide, a Mercy and Glad tidings to Muslims (Q. 16: 89).

Al-Qur'ān, and the Prophet Mohammad (p.b.u.h) who proclaimed it, are identified in these verses as the guides of mankind towards Allah's (swt) straight way. So, by virtue of its being revealed by Allah (swt) to the Prophet, Al-Qur'ann must be absolute in term of source, contents and ends. So, what Al-Qur'ān says about human being or human life as a whole, is absolute too. Hence, it rather must be sought to be correctly understood and adequately applied.

However, the case is otherwise if we are talking about manmade attempts that seek to understand the nature of human life as a whole. These are no more than a kind of attempts that are developed in the limits of human intellect. Furthermore, these attempts are subject to limitations, falsehood, and able to be questioned too. That is why Al-Qur'ān affirms that:

Mohammad is not the father of any of your men, but he is the Messenger of Allah, and the Seal of the Prophets; and Allah has full knowledge of all things (Q. 33: 40). 
That is, 'when a document is sealed, it is complete and there can be no further addition. The holy Prophet Mohammad (p.b.u.h) closed the long line of Messengers. Allah's (swt) teachings are and always will be ongoing, but there has been and will be no Prophet after Mohammad (p.b.u.h) and the later ages will only need thinkers and reformers that undertake the mission of remembrance to mankind, but no Prophets, 5 .

For the above reasons, Al-Qur'ān implied all what is needed to guide mankind to the straight path of Allah (swt), “... Nothing have We omitted from the book..." (Q. 6: 38), that is, for his happiness in both, the present life in terms of righteousness, integrity and probity, and in the hereafter in terms of reaching the pleasure of the Lord, Allah (swt) and the eternal happiness in the heaven.

Based on the analysis of the above-cited Quranic verses, one can ask the following questions.

\section{Does Al-Qur'ān Imply Any Theory of Educating Man to Qualify him for Such a Destiny in the Present Life and the Hereafter?}

One way to answer such a question is to explain why Al-Qur'ān has been revealed to mankind. Undoubtedly, the reason is that $A l$ Qur'ān has been revealed to mankind so as to be a prescribed law and a traced-out way in the present life:

$$
\begin{aligned}
& \text { "...shir'atan wa minhājan..." (Q. 5: 48) } \\
& \text { (...For each We have appointed a divine law = and a traced } \\
& \text { out way...) }
\end{aligned}
$$

Hence, it is obvious that to obey to any system, one should be first subjected to a certain process of educational adaptation that qualifies him to fulfill the requirements of such a system. Otherwise, he will not be apt to do so. From here, the necessity of a Quranic process of education emerges as an unavoidable prerequirement to a successful application of the Quranic way of life.

\footnotetext{
${ }^{5}$ The Holy Qur'ān, English translation of the meanings and commentaries (alMadinah al-Munawwarah) (Saudi Arabia: Holy Qur'ān Printing Complex, 1989), 1186.

${ }^{6}$ It is a part of the $48^{\text {th }}$ verse from surah al-Mā'idah which is the fourth surah in the Holy Qur'ān.
} 
Additionally, with reference to the Prophetic era, one can assert that this period had been the perfect application and actualization of the Quranic education that took the form of the Quranic model of both, man and society. So, a careful study of the Quranic model of education during the Prophetic era and his companions would enable us to realize that such a model of education had effectively been actualized in human life. For instance, one day, 'Aishah (r.a), the wife's Prophet, while asked about the virtues of the Prophet, she replied that he was a complete practical interpretation of $A l-Q u r ' a \bar{n}$, that is, Al-Qur'ān manifested itself through the behavior of the Prophet. Hence, he was the perfect model by excellence of the Quranic education by virtue of his being the example every Muslim must consider as his principal source of actualizing the meanings of $A l-Q u r$ 'an $n$ in his daily life's happenings, if a perfect eternal life is sought for:

"Verily in the messenger of Allah ye have a good example for him who looketh unto Allah and the Last Day, and remembered Allah much"' (Q. 33: 21).

However, since the source of such education is revelation (AlWahy), and its role model is performed by the Prophet (p.b.u.h), the system of education is unique in terms of conception, objectives, methods and means. So, Al-Qur'ān emphasizes the principle of al-Insān as-Sălih (the perfect man) whose mission in history is to actualize the meanings of the Quranic teachings as an illustrating model of the perfect Islamic education for nonMuslims in order to show them the straight way to happiness in the present life and in the hereafter. This is because, Al-Qur'än is the last word of Allah (swt) to the human race as a whole and not limited to Muslim people, as it is misunderstood by many people in the world.

Because of all these considerations, Al-Qur'ān adopts a comprehensive approach so that all the dimensions of human personality, body, spirit and mind, are taken into account. It regards human being as he is in his real life with his innate nature, weaknesses and strengths and as a unified entity where we cannot separate between mind, spirit and body since they function altogether to fulfill human needs. 


\section{The Required Methodological Considerations to Address the Model of Education in Al-Qur'ān}

To approach the project of educating human being from the Quranic perspective, we see the necessity to point out to some methodological requirements that are, in our view, necessary to address the foundations of the Quranic model of education and ensure an adequate understanding of such an approach. Below is a brief analysis of the following requirements:

○ A revealed model.

○ A principal reference, Al-Qur'ān.

○ A historical experience.

$\circ$ A realistic perspective.

\section{A Revealed Model}

The most outstanding aspect of Al-Qur'ān and as-Sunnah's analysis of the philosophical foundations is their complete distinction from the attempts made by mankind. Al-Kurdi, asserts that "when discussing the issue of the nature of knowledge in $\mathrm{Al}$ Qur' $\bar{a} n$, the matter is, from the beginning, totally different from any man-made philosophical attempts by virtue of its being a source of knowledge based uniquely on revelation", 7 . It is observed in this context that "human theories about ultimate realities based on reason never achieved the level of certainty and their authors conscious of their limitations, do not present them as conclusive proved", 8 .

Based on the above, Al-Qur'ān is not only a source of revealed knowledge, but also a standard for evaluating human knowledge itself ${ }^{9}$. On this basis, it is necessary to consider this difference and this distinction between Al-Qur'ān as a reveled source of knowledge and the man-made philosophical attempts in the field of education in the general sense of the term, and elaborated either by the Muslim or non-Muslim scholars.

7 Rājịh Abd al-Hamīd al-Kurdī, Nadhariyyat al-Ma 'rifah Bayna al-Qur'ān wa al-Falsafah (Theory of Knowledge Between Al-Qur'ān and Philosophy) (Riyadh: Dār al-Mu'ayyid, 1992), 429.

8 Altaf.Gauhar, The Challenge of Islam (Kuala Lumpur: Percetakan Zafar, Sdn Bhd., 1978), 5.

9 Al-Kurd̄̄, Nadhariyyat al-Ma 'rifah Bayna al-Qur'ān wa al-Falsafah, 429. 


\section{A Principal Reference, Al-Qur'ān}

From Al-Qur'ān's perspective, the philosophical foundations of education should be discussed as developed in Al-Qur'ān and asSunnah. Books of tafsir (exegesis) represent the principal source of reference. The comments of Muslim or, non-Muslim scholars on the matter are mentioned merely as a supporting evidence since the basic reference is tafsir of Al-Qur'ān and as-Sunnah. This is because the Islamic theory of education is fundamentally based upon the Quranic concepts ${ }^{10}$. Pointing out the difference between the Quranic educational teachings and the attempts of the Muslim scholars to grasp the essential elements of such an educational philosophy is a matter of a great necessity. The consideration of the Quranic educational concepts, i.e. man, society, knowledge, aims of education, as the philosophical foundations of education is based on the assumption that these concepts form the basic elements on which the theory of education is set upon. Together, these concepts are referred in this study as the basic elements of the Quranic philosophy of education. However, when dealing with the above-mentioned concepts, it will not be focused on the analysis of the theoretical-linguistic analysis of the terms since this kind of analysis is provided by other related studies. Hence, the functional dimension of the terms as used in Al-Qur'ann is emphasized.

\section{A Fruitful Historical Experience, Islamic Legacy}

The historical experience of the Muslim world confirms that the Quranic theory of education had been actually adopted on the ground by Muslims either in the Prophetic era or the Prophet's companions. Austin (1978) supports this view and asserts that Islam draws together many strands of truth expressed in the Judaic and Christian traditions, creating from the synthesis the complete and final form of Allah's religion. So, the life of the Prophet Muhammad (p.b.u.h) unites in one man the truth about man. In his life, the Prophet (p.b.u.h) combines the dual role of man as solitary and social being, as slave and vicegerent of Allah (swt), as a servant and messenger, Prophet and king. He is the archetype or

\footnotetext{
${ }^{10}$ Mentioning to Al-Qur'ān must necessarily include as-Sunnah since the latter is the explanation and the perfect application of Al-Qur'an. So, it will not be needed to mention to as-Sunnah whenever Al-Qur'ān is mentioned.
} 
norm of humanity by excellence in which all aspects of being unite at the center in perfect harmony and balance ${ }^{11}$. Also, AlMawdūdī, asserts that 'this reality is not a dream or utopia. The Prophet of Islam and his companions developed and established a complete model of Islam on earth for mankind to follow, ${ }^{12}$.

Furthermore, the ideas, which are discussed briefly in one location in al-Qur'ân, they may be discussed in more detail in another in order to be more appropriate to human understanding and real application because $A l-Q u r^{\prime} \bar{a} n$ is an integral book and not merely a segment of unrelated verses. So, the indispensability to deal with Al-Qur'ān from an integral point of view is imperative and emerges as a methodological necessity to ensure an accurate understanding of its meanings and their implications as well.

\section{A Realistic Perspective}

By its harmony, integration and inclusiveness of the different dimensions of human personality such as physical, spiritual, mental/ intellectual, moral, social emotional, etc., as well as the other foundations i.e. society, knowledge and aims of educations, Al-Qur'ān provides a particular view about $\operatorname{man}^{13}$. This is because Al-Qur'ān deals with human nature from a realistic perspective. This perspective takes human being as he is in his real life with respect to the whole above-mentioned dimensions of his personality.

\section{Future Perspectives - What Requirements for Future Education in the Muslim World?}

\section{How to Approach the Desired Educational Model}

As a way out from the problematic situation the Muslim world is facing since many centuries of failure and decline, it becomes crucial to emphasize the necessity to elaborate some parameters that should be observed whenever an attempt is sought for to conceptualize the required educational model. In other word, whenever, there is an attempt to think about the educational

\footnotetext{
${ }^{11}$ Altaf.Gauhar, The Challenge of Islam, 71.

${ }^{12}$ Altaf.Gauhar, The Challenge of Islam, 14.

${ }^{13}$ Muhammad Quṭb, Al-Insān Bayna al-Māddiyah wa al-Islām (Man Between Materialism and Islam), 10th edition (Beirut: Dār Esh-Shurūq, 1987), 69.
} 
problem in the Muslim world, it is imperative to take into account a set of suggested parameters that may help to adequately approach such a problem in terms of its conceptualization or the elaboration of the practical procedures of its resolving. These parameters are as follows:

$\circ$ Religion as a cosmic phenomenon.

- Innate religiosity of man or human being as a religious creature.

○ The nature of the Muslim world's civilizational cycle.

o The position of the Muslim world in history and its historical mission.

- Islam as the principal frame of reference.

o Post civilized Muslim man as the central factor in the Muslim dilemma.

o Integrated Muslim man as the central aim of the educational reform project

- Islamic Cultural heritage and Human historical experience.

$\circ$ Below are a short analysis of these suggested parameters.

\section{Religion as a Cosmic Phenomenon}

Religion is a focal issue of interest and an axial theme in the studies that are concerned with human condition. In fact, it is a "psychological force underlying human existence and determining human culture and civilization. Rather, it is the independent force on which human life stands and the source of the worldview, which any civilization adopts. For these considerations, religion appears as a cosmic phenomenon regulating the thought and civilization of $\operatorname{man}^{14 \text { " }}$ This is to emphasize the function of religion in human life in form of a regulative force that orients, conditions and adapts human vital energy in function with the requirements of the successful achievement of the historical mission. That is, "religion as a regulative psychological force plays a direct role in shaping the individual conscious ego and in regulating the vital energy, which originates from the natural instinct and is made subservient to the self ${ }^{15}$ ".

${ }^{14}$ Malik Bennabi, Al-Dāhirah al-Qur'āniyyah (The Quranic Phenomenon), $3^{\text {rd }}$ edition (n.p.: I.F.S.O 1983), 360.

${ }^{15}$ Malik Bennabi, Milād Mujtama', 72, and On the Origins of Human Society, trans. Mohammad Țāhir al-Messawi, 83. 
It has to be noted here that in different cultural context, the concept of religion is not limited to Islam or any revealed message, but also to any source of inspiration, that leads human vital energy to perform a determined mission inspired by the cultural ideals of a given society. However, in Islam, it is axiomatic that the principal and unique source of inspiration is revelation, that is, $A l-Q u r^{\prime} \bar{a} n$.

From this view, it becomes obvious that religion assumes a fundamental function in human life. This is despite that certain philosophies do not acknowledge the existence of such a dimension in human nature since atheism and agnosticism are just as much acts of faith as positive religious commitment. Hence, "whatever attitude we adopt towards religion - whether it be positive, negative or non-committal will inevitably have fundamental implications for our spiritual lives and ultimate concerns ${ }^{16 \%}$.

Hence, from an educational point of view, the role of religion in the process of educationally conditioning and adaptation of human personality, and organizing human behavior with regard to its relation with society is highly emphasized. In this context, the role religion plays, as a regulative psychological force of the vital energy, should be taken into consideration. Furthermore, since this individual's organized vital energy is converted into a social activity in form of a concerted action of society in history, this clearly shows the importance of the role played by the religious factor into different ways ${ }^{17}$ ". The role of religion, therefore, concerns in this context the process of transforming human vital energy into an efficient social behavior where the individual adapts it according to the law of religion.

From this perspective, religion, through its educational transformation of human vital energy, imparts to human existence its civilizational dimension. That is, to transform man into a civilized being who strives to actualize the aims of human existence as revealed by the divine Will.

\footnotetext{
${ }^{16}$ Andrew Wright, Spirituality and Education (London and New York: Master class in education series, Routledge Falmer Publication, 2000), 27.

${ }^{17}$ Malik Bennabi, Milād Mujtama', 72 and On the Origins of Human Society, trans. Al Missawi.M.T, 83.
} 
As a matter of fact, religion becomes not only a source of spiritual inspiration for mankind, but also an educational factor that orients guides and controls human behavior in the societal life while moving towards civilization.

The role of the religious idea in the synthesizing civilization manifests itself by the fact that "the great changes in history owe to religion a great thanks to the extent to be inconceivable to approach human history from only a naturalistic perspective ${ }^{18 \text { ". It }}$ is the motor-force of any civilization in history. That is to mean, religion is the catalyst that enables such an equation to acquire its dynamic and start moving in history to build a civilization.

The genesis of human civilization is a support for this view because civilization does not emerge, but upon a religious faith. It does not emerge in any human society but in form of a revealed message sent down from the heaven to be a guidance and source of inspiration for mankind. Civilization, in its essence, emerges to guide mankind to a metaphysical idol in general.

Malik Bennabi elucidates this fact by asserting that "for as back as we look into the past history of man either into the most advanced periods of his civilization or into the most rudimentary stages of his social evolution, one always finds a trace of religious thought. Customs and habits of people are modeled by metaphysical preoccupation. Totemisms, mythology, and theologies are expressions of this preoccupation that hunts human consciousness when it is seized by the enigma of the material world and its ultimately mysterious nature ${ }^{19,}$.

According to Wright, religion inscribes itself as one of the essential components of human nature. Rather, as an innate nature, and whatever would be its shape or way of actualization, religious belief manifests itself as the highest reality that can be observed in human life. So, he asserts that "the material-spiritual dualism is rooted in humanistic belief that our souls constitute the highest reality in the universe, and that the ultimate meaning of life is wrapped up with our spiritual well-being. So, the question

${ }^{18}$ Malik Bennabi, Wijhat al-Ālam al-Islāmī (Vocation de l'Islam), $5^{\text {th }}$ edition, (Damascus: Dār al-Fikr, 1986), 154 and Malik Bennabi, Islam in History and Society (Vocation de l'Islam), trans. Asma Rachid (Islamabad: Islamic Research Institute: International Islamic University, 1988), 116.

${ }^{19}$ Malik Bennabi, Al-Dāhirah al-Qur'āniyyah, 17. 
of religious commitment is universal and unavoidable and cannot simply be treated as an optional extra confined to religious believer". ${ }^{20}$ Hence, "Many scholars confirm the educational dimension of the role of religion in human life. Wright asserts again that religion is an inevitable dimension in schooling so as it is impossible to ignore the fact that religion in general continues to play a significant role in schools" $" 21$.

Despite the above considerations that relate to the nature of religion and its influence on human life as a whole, the historical evolution of the Muslim world's civilization witnessed the emergence of a new deviated form of religiosity that lost its influence on the course of Muslim society in history. So, religion turned into an individual concern that has nothing to do with the societal life either in terms of conditioning the individual's vital energy or organizing the social relations' network through which the individual fulfills his social function or, as Malik Bennabi puts it, "now, the Muslim even the post al-Muwahhid Muslim had never abandoned his credo. Ha had remained a believer or more exactly a devotee; his faith had become inefficacious because it had lost its social radiation, becoming centripetal, individualist: the faith of the individual disintegrated from his social milieu ${ }^{22}$. And "indeed the idea of Islam itself whose impact on the early Muslim was resounding throughout history has no longer the same influence and power to orient and mould our behavior and actions as well as to shape our thinking and feelings ${ }^{23}$ ".

\section{Innate Religiosity of Man or Human Being as a Religious Creature}

According to Al-Qur'ān, once born, human nature is in an inborn natural disposition to religiosity. That is, in a state of fitrah, which marks man's ability to look beyond his earthly horizon. Human being manifests a continuous inclination to religiosity in a kind of

\footnotetext{
${ }^{20}$ Andrew Wright, Spirituality and Education, 8 \& 26.

${ }^{21}$ Andrew Wright, Spirituality and Education, 28.

22 Malik Bennabi, Wijhat al-Ālam al-Islāmī, $5^{\text {th }}$ edition (Vocation de l'Islam) (Damascus: Dār al-Fikr, 1986), 54 and Malik Bennabi, Islam in History and Society, 24.

${ }^{23}$ Malik Bennabi, Milād Mujtama' (Birth of Society), $3^{\text {rd }}$ edition (Damascus: Dār al-Fikr, 1986), 104 and On the Origins of Human Society (Birth of Society), 123-124.
} 
an ideal of moral perfection which human civilization has never ceased to seek as its ultimate end ${ }^{24}$. So, to worship Allah (swt) is an innate human need, and because of this universal reality one does not find that any stage of human history is void of any kind of worship, or religion ${ }^{25}$. As a matter of fact, religion is a natural component in human personality. However, the problem, man is continuously encountered with, is the extent to which he can success in determining the true path towards his True Lord, Allah (swt).

This innate religiosity underscores an aspect of the universal psychological background common to all individuals of human specie according to which every individual builds up his personality ${ }^{26 "}$. As a matter of fact, any society's historical movement, either in the form of social change, civilizational project or an educational system must essentially be inspired or based on the principle of the inherent religiosity of human being. So, it would be inconceivable to think about educating man and preparing him for his historical mission out of the consideration of the religious nature of his personality.

\section{The Nature of the Muslim World's Civilizational Cycle}

Muslims are concerned with a set of problems relating to their own civilizational cycle. Their problems do not relate to the world of $2016 \mathrm{ac}$, but to that of 1437 a.h. That is, the first refers to the Western civilization while the second refers to the Islamic civilization. As a matter of fact, whenever the statement of our problems is done from this perspective, one has thus put them in the appropriate historical context. That is, in the suitable civilizational stage from which civilization can resume its new cycle $^{27}$. Furthermore, "any form of problems and phenomena, have their own history and different course of development respective to the cultural and civilizational context in which they arise ${ }^{28 \%}$.

\footnotetext{
${ }^{24}$ Malik Bennabi Adh-Dāhirah al-Qur'āniyyah (The Quranic Phenomenon), 79.

${ }^{25}$ Altaf.Gauhar, The Challenge of Islam, 314.

${ }^{26}$ Malik Bennabi, Milād Mujtama' (Birth of Society), 69 and On the Origins of Human Society (Birth of Society), 80.

${ }^{27}$ Malik Bennabi, Shurūt an-Nahdhah (The Conditions of the Renaissance), (Damascus,: Dārul Fikr, 1989), 48.

${ }^{28}$ Malik Bennabi, al-Muslim fì Ālam Al-Iqtisād (The Muslim in the Realm of Economics) (Damascus: Dār al-Fikr, 1968), 60.
} 
This methodological remark is crucial to ensure the authenticity of the attempts whenever made.

\section{The Position of the Muslim World in History and Its Historical Mission}

It is of crucial importance to determine our position in history. So, Muslims need to be aware of, and have a clear understanding of which civilizational stage they are witnessing in a determined period of history. Consequently, once this understanding is ensured, it would be within one's reach to grasp the different factors that will formulate the starting point to resume a new historical movement toward civilization. One of the most difficult problems Muslims are facing is the inability to determine the point of departure in their attempt to resume a new civilizational cycle. Consequently, it becomes inconceivable for anyone to suggest any solutions unless he surpasses that state of ignorance and misunderstanding of the position of the ummah in history. Otherwise, "any attempt to make use of any successful foreign experience, as a solution with disregard of the cultural and civilizational context is an uninsured attempt. This is a crucial point of departure that must be put into consideration whenever any attempt of revivalism in the Muslim world is sought for.

\section{Islam as the Principal Frame of Reference}

Based on the fact that we are a religious society inspired by revelation (Al-Wahy), Islam should be adopted as the principal frame of reference to formulate the whole methodological approach to studying the problems of civilization in the Muslim world. Thus, Islam is the principal frame of reference for educating the Muslim man in order to re-qualify him to resume his mission in history as a vicegerent of Allah (swt).

So, the adoption of religion in any project that concerns human condition would not appear as an amazing issue since religion is a cosmic phenomenon, the religiosity of human being is an innate matter and revelation is the principal source of inspiration.

From this perspective, our efforts to revive our historical existence as a religious leading Ummah, must be based on the need to reconsider such a reality in any attempt that relates to 
human problems in order to impart to our efforts their historical significance that may ensure a certain relevance with regard to the temporal requirements of the current situation the Muslim world is witnessing.

However, due to certain historical circumstances, a historical divorce that occurred between religion and knowledge and took the shape of a paradoxical controversy in the aptation arise as an inevitable necessity. In other words, religion is a factor of educating man based on his innate religiosity. Furthermore, due to the fact that the Western civilization as a model that lost its ability to inspire any new alternative in the Muslim world, and particularly in moral and spiritual values, the Muslim world can no longer seek guidance out of its own cultural boundaries that are crucial to ensure its peculiarity, authenticity and efficiency ${ }^{29}$," Because of this view, it is worthwhile to mention the necessity of such a requirement ${ }^{30}$ whenever one approaches the issue of how to formulate the project of renaissance in the contemporary Muslim world. The insistence on the matter may reach the extent to be considered as a constant law or more exactly a Sine Qua Non in any attempt to extract the Muslims from the enduring historical stagnation and marginality since many centuries.

Thus, Islam is an indisputable requirement that must be observed in this context. Based on the above, one should not content with a mere call for Islam as a frame of reference. However, one should try to bring into the attention of the Muslims the importance of such methodological requirements and develop the necessary practical mechanisms to actualize such a project.

\section{Post Civilized Muslim Man as the Central Factor in the Muslim Dilemma}

In the case of the current situation of the Muslim lands where the Islamic civilizational cycle has already been achieved and the Muslim man is in a state of historical resignation despite the different attempts undertaken in many parts of the Muslin lands to regain its original position in history, there is a persistent need to

${ }^{29}$ Malik Bennabi., Wijhat al-Ālam al-Islāmi (Vocation de l'Islam), 138, and Malik Bennabi, Islam in History and Society (Vocation de l'Islam), 71.

${ }^{30}$ See for instance Malik Bennabi's Mushkilah al-Thaqāfah (Problem of Culture) Damascus: Dār al-Fikr), 1986. 
distinguish between two types of man, the pre-civilized man and the post-civilized man. The reason is that each type requires a certain kind of education. So, "unlike the former (pre-civilized man), the latter (post-civilized man) is a source of many difficulties, which may entangle society's movement towards civilization. Thus, he is more difficult to be managed [or to be reeducated $]^{31}$ ". Such a difficulty can be justified by the fact that the post-civilized man i.e. the contemporary Muslim man, is a disintegrated individual who has already accomplished his historical mission. However, although he shares with the natural pre-civilized man the state of being out of history, he is unable to perform any new oevre civilisatrice (civilizing work) unless he is educationally reformulated. On the contrary, the pre-civilized man is in a state of complete readiness and disposition to enter in a new cycle of civilization. This is the case, for instance, of those bedouins in the time of the prophet Mohammed (p.b.u.h)' who were in complete readiness to accomplish that oevre civilisatrice $^{32, "}$.

In order to justify the need of a systematic reformulation of the Muslim man personality, it is worthwhile to mention that 'the final disintegration of the synthesis of Muslim man, soil and time manifests itself "everywhere [in the Muslim world], by the same symptoms of a general collapse marked the point of inflexion of the curve as a final result of a gradual process of losing our social religiousness. Consequently, in this vacant period, "the work of sciences loses all significance since wherever there ceases the radiation of the soul the rational work also comes to a stop and man loses the thirst to understand and the will to act ${ }^{33 \%}$. As a result of such a collapse, reason disappears, the intellectual works becomes worthless and the phase of decadence and man, soil and time were no longer the factors of civilization, but inert objects without creative inter-course that dynamites human energy to transform human behavior in a purposeful one towards history".

\footnotetext{
${ }^{31}$ Malik Bennabi, Ta'ammulāt (Reflections), Reprint of $1986^{\text {th }}$ edition (Damascus: Dār al-Fikr, 1986), 25.

${ }^{32}$ Malik Bennabi, Shurūt al-Nahdah, 70-71.

${ }^{33}$ Malik Bennabi, Wijhat al-Älam al-Islami (Vocation de l'Islam), 36 and Malik Bennabi, Islam in History and Society (Vocation de l'Islam), 13.
} 
So, as it becomes obvious, the post-civilized era is marked by a state of general stagnation that befell Muslim lands because the Muslim as a post-civilized man gave up to achieve any form of efficient historical contribution. This state of stagnation is due to that [psycho-] social pathology that spread through society, since many centuries, to the extent that the network of social relations became corrupt and disintegrated since "conceit became the dominating device and self-gratification submerged the selves in such a manner that any collective action became difficult, indeed impossible ${ }^{34 \text {, }}$

\section{Integrated Muslim Man as the Central Aim of the Educational Reform Project}

Once the process of educational conditioning and adaptation is achieved and the individual has been qualified to be integrated into society and resume his historical mission, he then reaches the stage of being an integrated man with whom history resumes its cycle of civilization, as Malik Bennabi puts it, "history commences with the integrated man, constantly adapting his efforts to his ideals and needs and accomplishing in society his double mission of actor and witness ${ }^{35}$ ". Based on the analysis of this term, one can realizes that it encompasses a psychoeducational condition where the individual has acquired the requirements that qualify him to contribute to the re-making-of history and producing a civilization. In such a condition, mankind has reached the model that qualifies him to successfully achieve his historical mission as prescribed by society's cultural archetypes.

\section{Islamic Cultural Heritage and Human Historical Experience}

We are a living Ummah with a heritage. Our heritage lives in us. It is our religion, culture, civilization, and our historic glory. No one can say that our historic glory will avail nothing today, because our history is an everlasting stock that provides us with hope, mental and psychological strength, and self-confidence. All this leads us to say that we are standing on firm grounds, backed up by an extremely rich stock of cultural heritage. All we need is the will

\footnotetext{
${ }^{34}$ Malik Bennabi, Milād Mujtama' (Birth of Society), 43.

${ }^{35}$ Malik Bennabi, Milād Mujtama' (Birth of Society), 43.
} 
to perform an effective civilizational act so as to confront the civilizational challenges. This entails developing our educational programs and curricula, promoting scientific research through doubling the budget earmarked for it and making our first priority in our national policies. It also necessitates strengthening our joint cooperation in all these fields, and changing, developing and modernizing our public life so that it can proceed along the right path and be in harmony with our values and principles. Only when we actualize these ideals, we'll be able to confront present and future challenges

\section{Conclusion}

To conclude this article, and based on its central concern, the methodological requirements to studying the issue of Education in al-Qur'ān, it is recommended for Muslim educators concerned with theorizing for contemporary Islamic education to observe the necessity to consider such requirements. Furthermore, they should be adopted in the form of a framework that form a kind of a methodological approach that may enable those researchers to elaborate the essential components of a new theory of education for the contemporary Muslim world.

\section{References}

Abd al-Hamīd al-Kurdī, Rājị̣. Nadhariyyat al-Ma 'rifah Bayna alQur'àn wa al-Falsafah (Theory of Knowledge Between AlQur'ān and Philosophy). Riyadh: Dār al-Mu'ayyid, 1992.

Al-Nadwī, Abū al-Ḥasan. Mādhā Khașra al-Ālam Binhițāt alMuslimin (What Did the World Loose with the Decline of the Muslims). Damascus: Dār al-Kalām, 1999.

Bennabi, Malik. Al-Dāhirah al-Qur'āniyyah (The Quranic Phenomenon), 3rd edition. N.p.: I.F.S.O 1983.

Bennabi, Malik. Al-Muslim fì Ālam Al-Iqtisād (The Muslim in the Realm of Economics). Damascus: Dār al-Fikr, 1968.

Bennabi, Malik. Islam in History and Society (Vocation de l'Islam), trans. Asma Rachid. Islamabad: Islamic Research Institute: International Islamic University, 1988.

Bennabi, Malik. Milād Mujtama' (Birth of Society), 3rd edition. Damascus: Dār al-Fikr, 1986. 
Bennabi, Malik. Shurūt an-Nahdhah (The Conditions of the Renaissance). Damascus: Dārul Fikr, 1989.

Bennabi, Malik. Ta'ammulāt (Reflections), Reprint of 1986th edition. Damascus: Dār al-Fikr, 1986.

Bennabi, Malik. Wijhat al-Ālam al-Islāmī (Vocation de l'Islam), 5th edition. Damascus: Dār al-Fikr, 1986.

Fī Dhiläl Al-Qur'an (In the Shadow of the Qur'ān), 22nd edition. Beirut: Dār ash- Shurūq, 1982.

Gauhar, Altaf. The Challenge of Islam. Kuala Lumpur: Percetakan Zafar, Sdn Bhd., 1978.

Malik Bennabi's Mushkilah al-Thaqāfah (Problem of Culture). Damascus: Dār al-Fikr, 1986.

On the Origins of Human Society, trans. Mohammad Țāhir alMessawi. Kuala Lumpur: The Open Press, 1998.

Quțb, Muḥammad. Al-Insān Bayna al-Māddiyah wa al-Islām (Man Between Materialism and Islam), 10th edition. Beirut: Dār Esh-Shurūq, 1987.

Qutb, Seyyed. The Milestones. Beirut \& Damascus: I.I.F.S.O, The Holy Qur'ān Publishing House, 1978.

The Holy Qur'ān, English translation of the meanings and commentaries (al-Madinah al-Munawwarah). Saudi Arabia: Holy Qur'ān Printing Complex, 1989.

Wright, Andrew. Spirituality and Education. London and New York: Master class in education series, Routledge Falmer Publication, 2000. 